\title{
PEMBERDAYAAN EKONOMI PRODUKTIF PADA SANTRI PESANTREN AT-TAQWA, KAB. SUMEDANG MELALUI BUDIDAYA MAGOT LALAT TENTARA HITAM (Hermetia illucens) SEBAGAI AGEN BIOKONVERSI LIMBAH ORGANIK SEKALIGUS SUMBER PAKAN TERNAK TINGGI PROTEIN
}

\author{
Ateng Supriyatna, Tri Cahyanto, Ucu Julita, Adisty Virakawugi Darniwa, Ayuni Adawiyah, \\ Yuni Kulsum, dan Afriansyah Fadillah \\ Jurusan Biologi, Fakultas Sains Dan Teknologi, UIN Sunan Gunung Djati Bandung \\ E-mail: atengsupriatna@uinsgd.ac.id
}

\begin{abstract}
ABSTRAK. Permasalahan kemiskinan dan lingkungan masih menjadi perhatian utama pemerintah pusat maupun daerah. Program yang dilakukan oleh pemerintah yaitu dengan mengembangkan program pemberdayaan sumber daya manusia terutama yang berusia muda. Melalui program pengabdian masyarakat berbasis pesantren diharapkan dapat meningkatkan peran santri pondok pesantren At-Taqwa, Kabupaten Sumedang Jawa Barat dalam pemberdayaan ekonomi kreatif sehingga mampu meningkatkan kesejahteraan santri dan masyakat sekitar pesantren. Model pendekatan yang diterapkan dalam pelaksanaan pemberdayaan ini adalah pendekatan partisipatoris sekaligus pemberdayaan masyarakat berbasis asset atau resources. Budidaya magot lalat tentara hitam (hermetia illucens) sebagai agen biokonversi limbah organik sekaligus sumber pakan ternak tinggi protein ini merupakan program yang berhasil menginisiasi perkembangan ekonomi kreatif di kalangan santri At Taqwa.
\end{abstract}

Kata Kunci : Ekonomi Kreatif; Black Soldier Fly (BSF); Pengabdian Masyarakat; Pesantren

\begin{abstract}
Poverty and Environmental Issues are still the concern of the central and regional governments. The program carried out by the government is by developing human resource empowerment programs supported by young people. Through the pesantrenbased community service program it is expected to increase the role of At-Taqwa Islamic boarding school students, Sumedang Regency, West Java in the empowerment of the creative economy so as to be able to improve the welfare of students and the pesantren community. The asking model applied in the implementation of empowerment is asking for participatory when empowering people based on assets or resources. Magot cultivation of black army flies (hermetia illucens) as an organic waste bioconversion agent as well as a source of high protein animal feed is a program that has successfully initiated the development of creative economy among students in Taqwa.
\end{abstract}

Keywords: Creative Economy; Black Soldier Fly (BSF); Community Servyce; Islamic Boarding School

\section{PENDAHULUAN}

Indonesia memiliki permasalahan di bidang kemiskinan dan lingkungan yang sampai saat ini masih menjadi perhatian utama pemerintah pusat maupun daerah. Menurut Badan Pusat Statistik (2019) penduduk miskin adalah penduduk yang memiliki rata-rata pengeluaran per kapita per bulan di bawah Garis Kemiskinan. Jumlah penduduk miskin di Indonesia pada September 2018 mencapai 25,67 juta orang. Dari sisi jumlah, sebagian besar penduduk miskin masih berada di Pulau Jawa $(13,19$ juta orang). Garis Kemiskinan pada September 2018 adalah sebesar Rp 410 670,- per kapita per bulan. Dibandingkan Maret 2018, Garis Kemiskinan naik sebesar 2,36 persen. Beberapa tahun ini angka kemiskinan berkurang tidak signifikan maka pemerintah membuat strategi dengan memunculkan program untuk meminimalisir masalah nasional tersebut.

Program yang dilakukan oleh pemerintah untuk menurunkan tingkat kemiskinan di masyarakat yaitu dengan mengembangkan program pemberdayaan sumber daya manusia terutama yang berusia muda. Salah satu programnya yaitu meningkatkan pertumbuhan wirausahawan muda yang menjadi pusat pengembangan potensi ekonomi lokal. Pendekatan yang umum dilakukan untuk mencapai hal ini adalah melalui berbagai kegiatan kewirausahaan maupun pelatihan pada usia muda.

Salah satu sumber daya usia muda terpusat di pesantren. Pesantren merupakan bagian dari tatanan pendidikan Islam yang memiliki tujuan untuk membentuk masyarakat madani yang sejalan dengan program pemerintah. Hal yang unik dari sistem pesantren adalah keragaman dari pola pendidikannya yang sangat dipengaruhi oleh kondisi masyarakat dimana pesantren tersebut berada. Kondisi ini merupakan modal besar yang apabila dikelola dengan baik dapat menjadikan pesantren sebagai motor perubahan sosial-ekonomi dan lingkungan.

Jawa Barat merupakan provinsi dengan jumlah penduduk terbesar di Indonesia dengan pesantren yang tersebar di seluruh wilayah. Berdasarkan Sekretariat Ditjen Pendidikan Islam Kementrian Agama RI (2011) mendata bahwa di Jawa Barat terdapat 4.323 pesantren dengan rentang jumlah santri sebanyak 80-300 orang putra dan putri setiap pesantren. Beberapa pesantren di Jawa Barat telah melakukan perubahan sosial dan ekonomi 
pada masyarakat sekitar mereka melalui kegiatan mikian, masih banyak pesantren yang masih belum memberikan pengaruh signifikan pada perubahan ekonomi, sosial, dan lingkungannya.

Permasalahan lingkungan yang banyak dikeluhkan salah satunya terkait masalah sampah terutam sampah organik. Adapun pengolahan sampah organik menjadi kompos telah banyak dilakukan namun secara ekonomi komersial masih rendah nilai jualnya. Melalui pendekatan bioteknologi sederhan dengan memanfaatkan maggot lalat tentara hitam dengan memanfatk maggot laht tentara hitam (Hermetia illucens) dapat memberikan alternatif solusi permasalahan sampah organik. Larva in memiliki potensi yang menguntungkan dari kemampuan magot lalat tentara hitam dalam mengonvers limbah organik menjadi biomassa tinggi protein untuk dijadikan sumber pakan ternak.

Berdasarkan paparan tersebut maka pengetahuan mengenaibudidaya maggotini perludiimplementasikan kepada masyarakat sebagai solusi untuk permasalahan yang teriadi. Melalui progrmm pengabdian masyarak berbasis pesantren ini secara tidak langsung berbasis pesan mern pesting pesan At-Taqwa, Kang Barat dalam pemberdayaan ekonomi kreatif dengan mengolah sampah organik sekitar pesantren sebaga media budidaya lalut tantara hitan un dijadika pakan ternak tinggi protein yang dapat digunaka sendiri atau dikomersilkan sehingga mampu meningkatkan kesejahteraan santri dan masyakat sekita pesantren.

\section{METODE}

Kegiatan ini dilaksanakan di lokasi Pondok Pesantren At Taqwa, Dusun Babakan Kawung RT 04 RW 03, Desa Sindangsari, Kecamatan Sukasari Kabupaten Sumedang. Bahan yang digunakan dalam pelatihan yaitu telur lalat tantara hitam, limbah sayur pelatihan yaitu telur lalat tantara hitam, limbah sayur campuran, pakan ayam $511 \mathrm{BR} 1$, air, kapas, tissue,
dan daun pisang kering. Alat yang digunakan dalam dan daun pisang kering. Alat yang digunakan dalam
pelatihan ini yaitu kandang BSF berukuran 30X30 $\mathrm{cm}$, wadah plastik dengan ukuran $15.5 \mathrm{~cm}$ X $15.5 \mathrm{~cm}$ aret, sendok, timbangan, kayu, alat tulis, dan baskom

Model pendekatan yang diterapkan dalam pelaksanaan pemberdayaan di tengah masyarakat adalah pendekatan Partisipatoris sekaligus pemberdayaan masyarakat berbasis asset atau resources. Menurut Purwatuty (2018) pemberdayaan masyarakat berbasis asset atau resources merupakan sal sat model pengem dam a peser meng dalam alin besu sebuah tatanan kehidupan sosial di mana masyarak menjadi pelaku dan penentu upaya pembangunan lingkungannya.

Bentuk kegiatan pengabdian masyarakat dan wawasan budidaya magot, 2) praktek pelatiha budidaya biokonversi sampar organik, 3) aplikasi magot lalat tentara hitam untuk pakan ternak, 4) pelatihan dan pendampingan bisnis kewirausahaan 5) Monitoring internal dan eksternal, dan 6) Evaluasi.

\section{HASIL DAN PEMBAHASAN}

A. Survei Lokasi dan Potensi Tempat PKM

Pengabdian Kepada Masyarakat di Pesantren At-Taqwa diawali dengan kegiatan survei lokas untuk mengetahui kondisi pesantren, keadaan sumber daya manusia, dan potensi pesantren yang dapat dioptimalkan untuk dilakukan pendampingan. Menurut Widyasanti (2016) mengatakan survei dan penjajagan potensi suatu lokasi PKM dilakukan untuk mendapatkan data mengenai upaya pemanfaatan potensi lokal berserta permasalahan yang ada dilamnya.

Pesantren At-taqwa memiliki program pendidikan dan dakwah, sosial kemanusiaan, pemberdayaan ekonomi dan bimbingan keterampilan umat serta program seni, budaya, dan olah raga sebagai media dakwah. Kegiatan yang saat ini sudah berjalan dengan baik dan berkesinambungan adalah program pendidikan keislaman, sosial kemanusiaan dan budaya

Sedangkan program pemberdayaan ekonom dan bimbingan keterampilan umat masih minim dan belum terealisasi sesuai harapan dalam meningkatkan kesejahteraan santri dan masyarakat sekitar. Sehingga kegiatan pelatihan mengenai ekonomi kreatif in tepat diaplikasikan di pondok pesantren.

Permasalahan lingkungan di sekitar Pesantren At-Taqwa yaitu menumpuknya sampah organik yang berasal dari sampah pesantren dan sampah masyarakat sekitar lingkungan pesantren. Sampah organik yang dihasilkan oleh kegiatan pertanian dan peternakan masyarakat sekitar pesantren masi dikelola secara tradisional yakni dengan cara dibakar atau dijadikan pupuk kompos untuk tanaman Kegiatan peternakan masyarakat sekiar pesantren masih bergantung pada ketersediaan pakan komersial yang mahal dan pakan hijauan yang ketersediaannya masih bergantung musim.

B. Pelatihan Budidaya Magot Lalat Tentara Hitan (Hermetia illucens) sebagai Agen Biokonversi Limbah Organik sekaligus Sumber Pakan

Seiring dengan perkembangan zaman, ilmu pengetahuan pun semakin berkembang. Banyak penelitian yang dilakukan sebagai jawaban untuk permasalahan-permasalahan yang terjadi. Salah sat pengetahuan yang terus menerus dikembangkan adalah ilmu biologi. Persoalan-persoalan yang terjadi terutama dibidang lingkungan terus mencar opsi solusi menggunakan keanekaragaman hayati. Salah satunya adalah persoalan sampah organik yang bisa diminimalisir dengan menggunakan agen hayati berupa larva lalat tantara hitam.

Hermetia illucens yang masuk ke dalam kelompok Diptera: Stratiomyidae atau Lalat tentara hitam (Black Soldier Fly) merupa Lalat tentara organisme serangga penting di alom terutama terkait perannya sebagai serangga den 2010). $H$, illagi sampah organilk (Zhag dk, 2010). H. illucens mampu mereduksi akumulasi sampah organik hingga 50\% dalam waktu singkat sehingga mampu mengurangi polusi lingkungan secara optimal (Myers dkk., 2008)

Saat ini $H$. illucens banyak dimanfaatkan dalam bidang bioindustri melalui biokonversi berbagai limbah organik menjadi produk biomassa prepupa untuk dijadikan sumber pakan ternak tinggi protein (Diener dkk., 2009), biomassa tinggi lemak untuk sumber bahan baku energi alternatif terbarukan (Li dkk., 2012), sumber asam amino, asam lemak (Li mineral (Spranghers dkk, 2016) serta sumber chitin dan chitosan (Kumar, 2000).

Magot $H$. illucens memiliki kemampuan untuk mengonsumsi berbagai jenis limbah organik seperti kotoran hewan, kotoran manusia, daging busuk, buah-buahan, sayuran, limbah restoran, limbah dapur, dan limbah pertanian berselulosa tinggi (Nguyen, 2010; Holmes; 2010, Sheppard dkk, 2002; Tomberlin dkk, 2002, Supriyatna, 2017).

Kegiatan pengabdian melibatkan peserta pelatihan yang merupakan santri pondok pesantren AtTakwa dan masyarakat umum, lembaga DT Peduli, dan Civitas Akademika Jurusan Biologi. Kegiatan pengabdian diawali dengan pembukaan berupa sambutan dari pihak-pihak yang terlibat.

Selanjutnya pemberian materi, materi pembuka yaitu mengenai urgensi wiraniaga dalam Islam yang disampaikan dengan metode ceramah. Tujuan pemberian materi ini adalah untuk memberikan wawasan kepada santri mengenai pentingnya berwiraniaga dan memotivasi agar tertarik terjun dalam dunia wiraniaga. Selain bermanfaat untuk diri sendiri, berwiraniaga dapat membantu banyak orang terutama masyarakat sekitar pesantren. Target yang harus dicapai adalah pesantren menjadi poros pembangunan sosial dan santri sebagai penggeraknya.

Materi kedua yaitu materi inti pelatihan mengenai pengenalan lalat tantara hitam. Pada materi ini dijelaskan mengenai deskripsi, fungsi, manfaat, dan cara budidaya larva lalat tantara hitam. Para peserta pelatihan masih sangat asing dengan jenis peserta pelatihan masih sangat asing dengan jenis
serangga ini sehingga sangat antusias dalam mengkuti kegiatannya. Metode yang dilakukan oleh pemateri adalah metode ceramah dengan bantuan slide materi yang diperkaya oleh gambar-gambar objek budidaya sehingga memberikan cukup gambaran untuk para peserta latihan.

Setelah pemberian materi selesai kemudian dilanjutkan dengan praktik cara budidaya lalat tantara hitam yang dilakukan dengan metode demonstrasi. Ilmu yang didapatkan dari hasil pemaparan materi langsung diaplikasikan agar peserta pelatihan dapa mengimplementasikannya secara perulh dilu

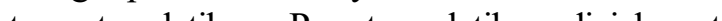
memprak untuk perp pertumbuhan untuk lalat tantara hitam dari sampa organik. Setiap peserta terlihat antusias dan memiliki peran yang sama dalam kelompok untuk terlibat. Setiap kelompok ditemani oleh satu pemandu untuk memastikan agar setiap tahap proses pembuatan media pertumbuhan dilakukan secara benar

Tahap pertama yang dilakukan yaitu pengenalan alat dan bahan yang digunakan serta tahapan dalam proses budidaya lalat tantara hitam sebaga agen biokonversi. Langkah awal dimulai dimula dengan proses pembuatan media pertumbuhan lala to hitam. Media tuma pertumbuha campuran cack limanaka

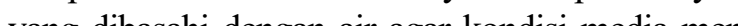
jadi lemb. Selujutny telur late tanta sebany 0,2 gin medi pert2 gan dhasukan ke dalan wada me pertur kain berwarna gelap dan disimpan di tempat yang lembab saat telur menetas (kurang lebih selama satu minggu).

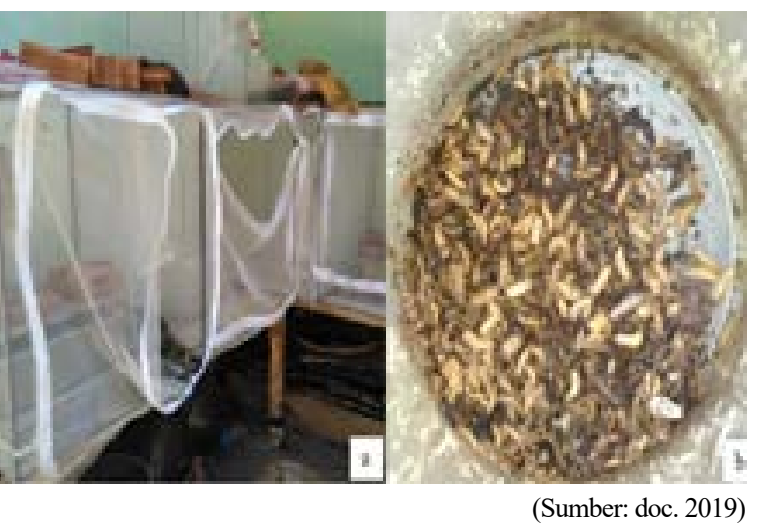

Gambar 1. Material Pelatihan a. Kandang Budidaya, b. Lary BS

Praktik yang dilakukan secara langsung bersama para peserta hanya pada saat pembuata media pertumbuhan. Setelah itu dijelaskan kembal mengenai tahapan selanjutnya berupa pemanenan larva lalat tantara hitam dan cara pengolahannya menjadi pakan ternak dengan metode demonstrasi tanpa melibatkan peserta pelatihan. Dalam pelatihan budidaya BSF peserta aktif bertanya dan mengemukakan pendapat pada sesi diskusi. Dalam kegiatan praktik ini terlihat para peserta sang antusias menerima ilmu terapan baru tersebut. 


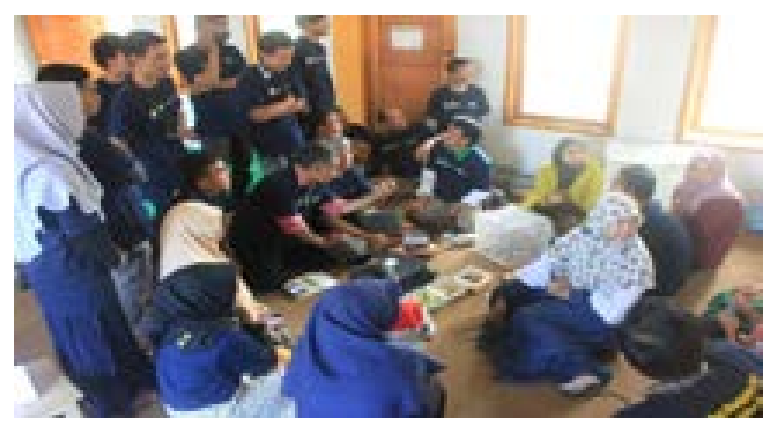

(Sumber: doc. 2019)

Gambar 2. Praktik Pembuatan Media Tumbuh BSF

Setelah proses pelatihan selesai, para pemateri melakukan evaluasi kepada para peserta pelatihan. Berdasarkan pengakuan salah satu peserta pelatihan mengemukakan bahwa pelatihan budidaya lalat tantara hitam ini sangat bermanfaat dan bisa menjawab permasalahan santri dan masyarakat sekitar pesantren berupa masalah perekonomian dan permasalahan sampah organik. Pengabdian berbasis pesantren ini menjadi stimulus untuk para peserta pelatihan agar terus menggali ilmu dan terus berkreasi dalam menyelesaikan permasalahan. Sehingga budidaya magot lalat tentara hitam (hermetia illucens) sebagai agen biokonversi limbah organik sekaligus sumber pakan ternak tinggi protein ini sebagai inisiasi perkembangan ekonomi kreatif di kalangan santri.

\section{SIMPULAN}

Pelatihan budidaya lalat tantara hitam ini sangat bermanfaat dan bisa menjawab permasalahan santri dan masyarakat sekitar pesantren berupa masalah perekonomian dan permasalahan sampah organik. Budidaya magot lalat tentara hitam (hermetia illucens) sebagai agen biokonversi limbah organik sekaligus sumber pakan ternak tinggi protein ini merupakan program yang berhasil menginisiasi perkembangan ekonomi kreatif di kalangan santri At Taqwa.

\section{DAFTAR PUSTAKA}

Badan Pusat Statistik. 2019. Profil Kemiskinan di Indonesia September 2018. No. 07/01/Th. XXII. https://www.bps.go.id/ pressrelease/2019/01/15/1549/persentasependuduk-miskin-pada-september-2018sebesar-9-66-persen.html

Diener, S. 2009. Conversion of organic material by black soldier fly larvae: establishing optimal feeding rates. Waste Management and Research 27: p 603-610. https://www.ncbi.nlm. nih.gov/pubmed/19502252

Holmes L, Vanlaerhoven S, and Tomberlin J. 2012. Relative Humidity Effects on the Life History of Hermetia illucens (Diptera: Stratiomyidae). Environmental Entomology, 41:97197. https:// academic.oup.com/ee/article/41/4/971/448259
Li Q, Zheng L, Qiu N, Cai H, Tomberlin J,Yu Z. 2012. Bioconversion of dairy manure by black soldier fly (Diptera: Stratiomyidae) for biodiesel and sugar production. Waste Management. 31:13161320. https://www.ncbi.nlm.nih.gov/ pubmed/21367596

Myers HM, Tomberlin JK, Lambert BD, David K. 2008. Development of black soldier fly (Diptera: Stratiomyidae) larvae fed dairy manure. Environmental Entomology 37: 1115. https://bioone.org/journals/environmentalentomology/volume-37

Nguyen T, Tomberlin J, VanlaerhovenS. 2013. Influence of Resources on Hermetia illucens (Diptera: Stratiomyidae) Larval Development. Journal of Medical Entomology. 50:898906. https:// www.researchgate.net/publication/255713326_ Influence_of_Resources_on_Hermetia_ illucens_Diptera_Stratiomyidae_Larval_ Development

Sheppard DC, Tomberlin JK, Joyce JA, Kiser BC, SumnerSM.2002. Rearingmethodsfortheblack soldier fly (Diptera: Stratiomyidae). Journal of Medical Entomology 39: 695-698. https://www. ncbi.nlm.nih.gov/pubmed/12144307

Tomberlin JK, Sheppard DC. 2002. Selected lifehistory traits of black soldier flies (Diptera: Stratiomyidae) reared on three artificial diets. Annals of the Entomological Society of America 95: 379-386. https://www.researchgate.net/ publication/232672374_Selected_LifeHistory_Traits_of_Black_Soldier_Flies_ Diptera_Stratiomyidae_Reared_on_Three_ Artificial_Diets

Purwatuty, Ida. 2018. Pemberdayaan Keluarga Miskin melalui Aset Komunitas. Jurnal Mimbar Kesejahteraan Sosial. Edisi 1. http://journal. uin-alauddin.ac.id/index.php/jmks/article/ download/7009/5788

Sekretariat Ditjen Pendidikan Islam Kementrian Agama RI. 2011. Data Pesantren di Jawa Barat. https://jabarkemenag.go.id/file/file/ BIDANGPEKAPONTREN/zbio1395976634.pdf

Widyasanti, Putri, S.H. dan Dwiratna. S.N.P. 2016. Aupaya Pemberdayaan Masyarakat Melalui Pelatihan Pembuatan Produk Sabun Berbasis Komoditas Lokal Di Kecamatan Sukamantri Ciamis. Dharmakarya: Jurnal Aplikasi Ipteks Untuk Masyarakat. Vol 5(1). http:// jurnal.unpad.ac.id/dharmakarya/article/ download/8869/5239

Zhang J, Huang L, He J, Tomberlin JK, Li J, Lei C, Sun M, Liu Z, Yu Z. 2010 An artificial light source influences mating and oviposition of black soldier flies, Hermetia illucens. Journal of Insect Science 10:202. https://www.ncbi.nlm.nih.gov/ pubmed/21268697 